\title{
ANALYSIS OF TRANSPORTATION COMPANIES IN THE CZECH REPUBLIC BY THE KOHONEN NETWORKS - IDENTIFICATION OF INDUSTRY LEADERS
}

\author{
Jakub Horák*, Petr Šuleř, Jaromír Vrbka \\ School of Expertness and Valuation, Institute of Technology and Business in Ceske Budejovice, Ceske Budejovice, \\ Czech Republic \\ *E-mail of corresponding author: horak@mail.vstecb.cz
}

\begin{abstract}
Resume
Computational models of artificial neural networks are currently used in different areas. Accuracy of results exceeds the performance of traditional statistical techniques. Artificial neural networks as the Kohonen map may be used e.g. to identify industry leaders, thus replacing the traditional cluster analysis and other methods. The aim of this contribution is to analyse the transportation industry in the Czech Republic by the Kohonen networks and identify industry leaders. The data file contains results - division of companies into a total of 100 clusters. Each cluster is subjected to analysis of absolute indicators and several parameters, average, as well as absolute, are examined. In total, 88 firms may be considered as industry leaders. Consequently, a fairly small group of companies has a strong influence on development of the whole transportation industry in the Czech Republic.
\end{abstract}

Available online: https://doi.org/10.26552/com.C.2021.1.A32-A43

\section{Article info}

Received 3 March 2020

Accepted 3 June 2020

Online 26 October 2020

\section{Keywords:}

Kohonen networks, artificial intelligence, industry leaders, transportation, cluster analysis

ISSN 1335-4205 (print version)

ISSN 2585-7878 (online version)

\section{Introduction}

Artificial neural networks (ANN) have become a frequently addressed topic over the last decade and currently they are inevitable in all the sectors, including transport. With their help, it is possible not only to analyse the large data files, but also to predict future development or to apply them in decision-making processes. Their application in the transport sector offers many advantages, which might become not only competitive. The need to use the ANN is constantly growing, and becoming an advantage that can both save time and improve results of analyses, as well as help where traditional methods are no longer sufficient. A significant deficiency in traditional methods is their inability to work with nonlinear data, or their problem with processing of large data files, and the perfect solution is to use the artificial neural networks. Demand for use of the neural networks in business processes has been constantly growing and range of their application is so wide that they will prove useful to a large number of users. However, using the ANN is not only a useful option, but for some companies it is a question of necessity, because, as already mentioned, there are issues where traditional methods of data processing can no longer be applied. Advantage in neural networks over the traditional methods is also seen by Horak and Krulicky [1], who say that the method of artificial neural networks has many advantages over the conventional methods. In the transport sector, one can find abundant use of the ANN, such as for processing data on consumer behaviour, prediction of train delays based on historical time data, or generally, in comprehensive evaluation of companies which is dealt with, for example, by Vochozka [2]. Neural networks can be also widely used in analysis of companies, as they were used e.g. by Machova and Vochozka [3], who analysed business companies in the Czech Republic using the artificial neural networks and subsequently estimated development of this sector of the national economy. Transport companies abound in a large amount of (not only) company data, which - thanks to their fast and efficient processing - can be transformed into useful outputs that provide companies with many benefits and predictions of the future development. Transport companies form an important component of the national economy in the Czech Republic, whether it is the transport of people, information, or freight. According to Svobodova, Veznik and Hofmann [4], the unprecedented importance of transport in the Czech Republic arises from its position at the crossroads of trans-European routes. Undoubtedly, the interior transport is also of a great importance in the Czech Republic, above all for the import and export of raw materials and products and especially for satisfying the need for interior and international passenger transport.

Artificial neural networks are in fact computational models that are inspired by biological neural networks, namely neuronal behaviour [5]. Use of these networks is, 
however, applicable in many different areas. According to Pao [6], neural networks are currently widely used to address potential future problems, in particular for value prediction. Horak, Vochozka and Machova [7] state that results of the neural networks are very promising, and their performance and accuracy when calculating a company's key performance indicators are significantly higher than those of the traditional statistical techniques. Sayadi et al. [8] argue that the main advantages of artificial neural networks are the ability to generalize, the ability to learn, etc. One of disadvantages of networks is that they require high data quality and possibility of illogical behaviour of the artificial neural network [9]. According to Grigoryev et al. [10], this illogical behaviour can be explained by the fact that a trained ANN classifies the observations according to its own criteria, which differ from the usual criteria used by humans. Therefore, using these unusual criteria, ANN can make fundamental errors in the non-standard irregular situations. Thus, some specific additional techniques are needed to detect such illogical behaviour. One of the major disadvantages is also the inability to estimate an error of the result, which is obtained by a neural network.

According to Vochozka and Machova [11], the artificial neural network is one of the most popular methods that is used as a prognostic method that requires a more complex model, uses more variables and tends to be nonlinear. Therefore, this method is suitable for auxiliary adjustments of the financial sector, especially in the stock market. The authors' study proves that the neural network, as a predictive model, could significantly outperform the minimum return.

Vochozka and Sheng [12] used the artificial neural networks to predict potential financial problems in transport companies in the Czech Republic. The result is a neural network, which, with accuracy exceeding $90 \%$, determines if a company is able to overcome potential financial problems, in how many years a company could go bankrupt or whether a company could fail within one calendar year. The model can be used in practice by leading transport companies, investors looking for a suitable company for capital investment, competitors, etc. [13], based on the presented data, demonstrated the classification capability of the Kohonen network model, one of the models of artificial neural networks. Using this approach to analysing a company can help to decide, quickly and easily, whether the company is healthy or in recession with respect to historical data. This is often a crucial requirement for the successful business activity in the area. According to Han and Wang [14], business analysis can be measured in different ways, but Kohonen networks are considered as a very attractive model. These networks can be used to group into different groups. Many experimental results show that Kohonen's networks are very effective for business valuation. Krulicky [15] noted that Kohonen's network is self-organized and is composed of an input layer that is interlinked to the output layer. Since it is an alternative network, it has a wide range of application that can be used for most neural network calculations.
According to Severin [16], separate Kohonen networks can be used to improve the time stability of the financial failure model. This model is successfully used for data mapping and its trajectory allows clustering and visualization of bankruptcy tendencies, offering new insights into models of business expansion in competition [17]. On the other hand, it serves as a tool for predicting the future bankruptcy and much relevant literature suggests such models [18].

Cluster analysis has many uses, not only in the transport sector. For example, Hitka et al. [19] applied the cluster analysis to define three motivationally oriented groups in the category of managers and three similar motivationally oriented groups in the category of employees, using the cluster analysis as a strategic advantage of human resource management in small and medium-sized enterprises in the woodworking industry. Furthermore, e.g. Vrbka and Rowland [20] used the neural networks to forecast stock price developments.

This article explores the Kohonen networks to analyse transport companies and therefore there is a need to briefly describe the specificities of transport companies and introduce some research on a similar topic. Transport companies provide public services and usually operate under the conditions of a natural monopoly [21]. Most authors categorize transport businesses by road, water, air, sea and rail and as public and non-public. As is well known, the process of globalization is a link between existing economies, with transport companies trying to meet the highest leading business standards [22]. This change in the transport market and acceleration of the cycle of external and internal changes in the transport companies brings extraordinary demands on top management in the area of management processes [23]. According to Ou et al. [24], a significant difference between the transport and other businesses is the focus on ecology. Traffic and transport companies have a far greater negative impact on the environment and, therefore, ecological issues of course concern them far more than the most of other companies. The transport sector has been one of the major factors contributing to environmental pollution in recent years. At present, many studies are working on the fuel consumption analysis in transport. Fuel types, including alternative fuel systems, have been compared, leading to a greater fuel technology development and, therefore, environmental protection.

Vochozka, Rowland and Vrbka [25], briefly presented the financial analysis, typical of transport and logistics companies and defined the financial characteristics of the average transport and logistics company in the Czech Republic. Based on the findings, they carried out a financial analysis of the average company, thus revealing the future potential of the transport and logistics sector in the Czech Republic. It can be said that the transport and logistics sector is financially sound and promising in the Czech Republic. SerokaStolka, Tomski and Pabian [26] analysed and evaluated the current situation of environmental management 
in the Austrian transport sector. The authors sought to identify the specific characteristics of the transport sector with regard to environmental protection. They stated that there are effective ways to increase the overall sustainable performance of transport companies, especially through planned route optimization, pooling or investing in efficient warehouses.

\section{$2 \quad$ Data and methods}

In terms of methodology, the text is related to [15]. For the purposes of the contribution, the same set of data is used. A data file was analysed, containing data on 3,989 companies operating in the transport sector in the Czech Republic in 2016. The data file comes from Bisnode's Albertina database. All the enterprises are included in the database in the given year according to the CZ NACE classification of economic activities; in the specified sector $\mathrm{H}$. Those are the complete financial statements of the companies. For the analysis itself, only certain items, expressing the main activity of the company, were used. Those items are not directly value generators, but they can have an impact, albeit indirect, on the company's performance. Those are the total assets (information on the size of the company), fixed assets (the level of technology used and the expected volume of performance - transport machines, i.e. cars, planes, etc.), current assets (the volume of funds, cash equivalents, account receivables and stock inventory), own resources (the degree of business risk), external resources (the external view of potential risks), performance (the production), added value (the value added by the company to the basic input - material), operating profit (how successful the company is in its activities), return on equity (the appreciation of equity) and profit before tax (a success or a failure of the company in its entire activity). The superstructure is to identify the transportation industry leaders in the Czech Republic. The contribution provides a deeper analysis of the previously obtained results.

The data file was subjected to cluster analysis using one type of artificial neural networks without a teacher, namely Kohonen networks. Dell's Statistica software version 12 was used. The data for the analysis was determined - in all the cases there were the continuous predictors. The data file was divided into three parts, of which the first - the training data set - contained $70 \%$ of the companies in the file. Based on this data set, a Kohonen network was created. The second part was a test data set, which contained $15 \%$ of the data and was used to verify parameters of the created network. The third part was a validation set, which also contained $15 \%$ of the data and was used to verify the created network and whether or not it was applicable.

The topology was based on the idea that it should be factually graspable, the length and width should not be too wide or too small (so that the level of detail is ideal). Prior to this research, a topology from $5 \times 5$ to $20 \times 20$ was tested and the most suitable one was determined to be $10 \times 10$. The topology is set in advance; it is a grid in the space of sample neurons. If only a single one was omitted, the grid would be irregular. It was also impossible to omit clusters that were not filled with real data, because in reality there may be a company that belongs to such a cluster. It is also impossible to find fewer clusters than the topology contains - it follows from the structure itself. The topological length and width of the Kohonen map was therefore set to 10 . The view was orthogonal, however the distance measured was Euclidean. A sample neuron was created; after that, the distance was measured according to the distance of a real neuron. The neuron was represented by a number. The specification and methodology of creating Kohonen networks in the given software were used. That created a total of 100 clusters, 100 neurons. The number of repetitions of the calculation (iteration) was determined to be 10,000 . However, the error level should be crucial - if the parameters did not improve with each subsequent iteration, the training would be terminated earlier. If, on the other hand, the network parameters improved, even during the final iteration, the whole process would be repeated and a higher iteration value would be set.

The results, namely the division of companies into 100 clusters, were imported to an Excel spreadsheet file. Consequently, each cluster was subjected to the analysis of absolute indicators. At this moment, the question should be answered, how an industry leader is understood. Numerous parameters can be selected, including, but not limited to:

- Volume of assets,

- Volume of fixed assets,

- Operating profit,

- $\quad$ Earnings before taxes (EBT).

The analysis has examined both average and absolute parameters of each cluster in order to establish:

- Most successful company clusters in the transportation industry.

- Most successful companies in the transportation industry.

The evaluation of return on assets and return on equity was also included in the analysis of absolute indicators. Return on assets (ROA) has shown the appreciation of capital invested in companies, or company clusters. Return on equity should, among others, document the attractiveness of each cluster for potential investors.

\section{Results}

Clusters were created using the applied methodology. The breakdown by representation of companies in each cluster of the Kohonen map is shown in Figure 1.

Figure 1 offers three-dimensional display of a Kohonen map and number of companies represented in each cluster. It is obvious from the graph that Cluster $(4,10)$ has the highest representation of companies. It is followed by Cluster $(4,9)$ and Cluster $(5,9)$ comes as the third. A hundred or more companies are also concentrated in Clusters $(6,10),(5,10),(2,6),(3,8)$ and $(1,6)$. The 

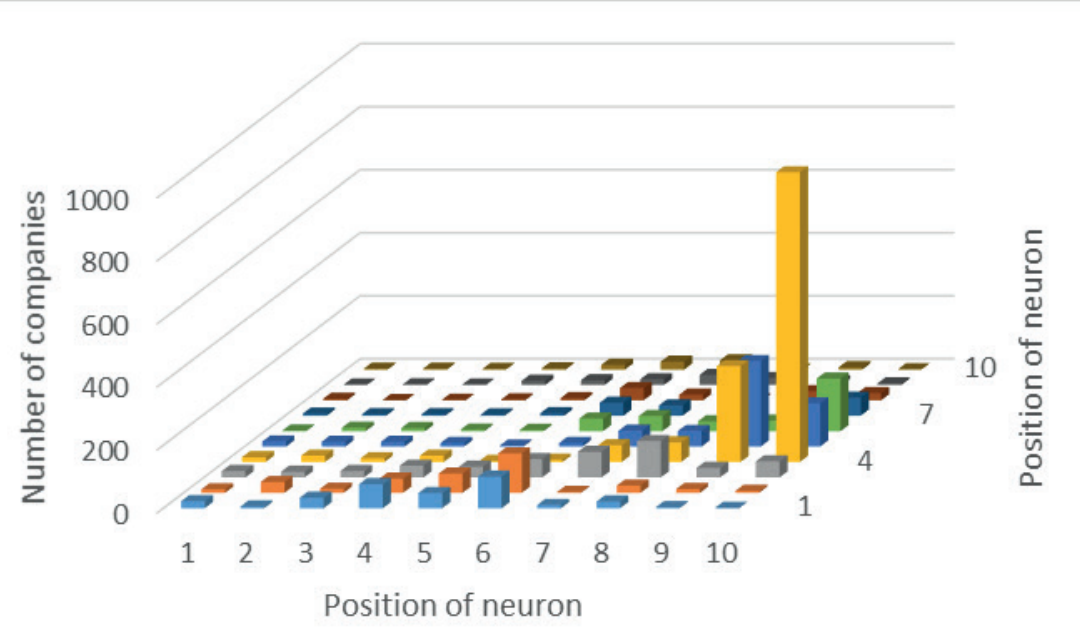

$\square 1 \square 2 \square 3 \square 4 \square 5 \square 6 \square 7 \square 8 \square 9 \square 10$

Figure 1 Breakdown by representation of companies in each cluster of the Kohonen map

Table 1 Representation of companies in Kohonen map clusters

\begin{tabular}{cccccccccccc}
\hline cluster position & 1 & 2 & 3 & 4 & 5 & 6 & 7 & 8 & 9 & 10 \\
\hline 1 & 22 & 5 & 33 & 76 & 48 & $100^{*}$ & 10 & 21 & 3 & 1 \\
2 & 11 & 34 & 13 & 45 & 61 & $125^{*}$ & 3 & 23 & 12 & 6 \\
3 & 20 & 18 & 20 & 37 & 34 & 58 & 81 & $115^{*}$ & 30 & 51 \\
4 & 15 & 20 & 12 & 20 & 3 & 7 & 53 & 62 & $304^{*}$ & $919^{*}$ \\
5 & 16 & 15 & 15 & 11 & 3 & 11 & 50 & 49 & $271^{*}$ & $137^{*}$ \\
6 & 2 & 11 & 10 & 5 & 4 & 40 & 48 & 31 & 33 & $167^{*}$ \\
7 & 7 & 5 & 5 & 4 & 8 & 41 & 33 & 8 & 21 & 57 \\
8 & 5 & 1 & 2 & 3 & 7 & 39 & 18 & 3 & 29 & 23 \\
9 & 1 & 2 & 1 & 13 & 15 & 18 & 32 & 22 & 12 & 5 \\
10 & 3 & 3 & 2 & 4 & 15 & 25 & 29 & 0 & 7 & 1 \\
\hline
\end{tabular}

remaining clusters show a considerably lower number of companies. By the same token, note that only one cluster of the Kohonen map remains unoccupied, namely Cluster (10, $8)$. Several clusters are formed by a single company: $(1,10)$, $(8,2),(9,1),(9,3)$ a $(10,10)$.

Figure 1 is supported by specific values listed in Table 1 to provide a detailed overview of companies in each cluster.

Table 1 shows that apart from the clusters above (marked "*" in the table) no other clusters include more than a hundred of companies.

Further, the transportation companies, or the transportation industry, were analyzed from two points of view:

- The prism of average values of companies represented in each cluster: to determine how companies are characterised in each cluster and to which extent their company activity is successful on average;

- The view of absolute values per cluster: to get information how each cluster affects the future development and success of the transportation industry in the Czech Republic.

\subsection{Analysis of average values}

The first parameter used is the average value of corporate assets per cluster (Figure 2).

In practice, there is a marginal rate of capital-labour substitution, i.e. the fixed assets for employees. It can be concluded that companies, which own a high volume of fixed assets implement a high number of contracts with a lower number of employees. However, there is a very specific marginal rate of substitution in transportation. It rather varies between modes of transport, e.g. rail transport is a lot more challenging than the road transport. Nevertheless, the volume of the fixed assets may predetermine the volume of incomes realized from a company activity. However, it was expected for that to be the assets necessary for operation (i.e. assets needed by the company to realize income). In the case of transportation companies, a cluster with high average values of assets was identified. It is Cluster $(10,1)$. It is followed by several clusters with highly above-average average values of the fixed assets. In particular, note Cluster $(10,2)$ and Cluster $(9,2)$. Clusters $(8,1),(9,3),(8,2)(9,1)$ and $(8,3)$ are also considered as very significant. 


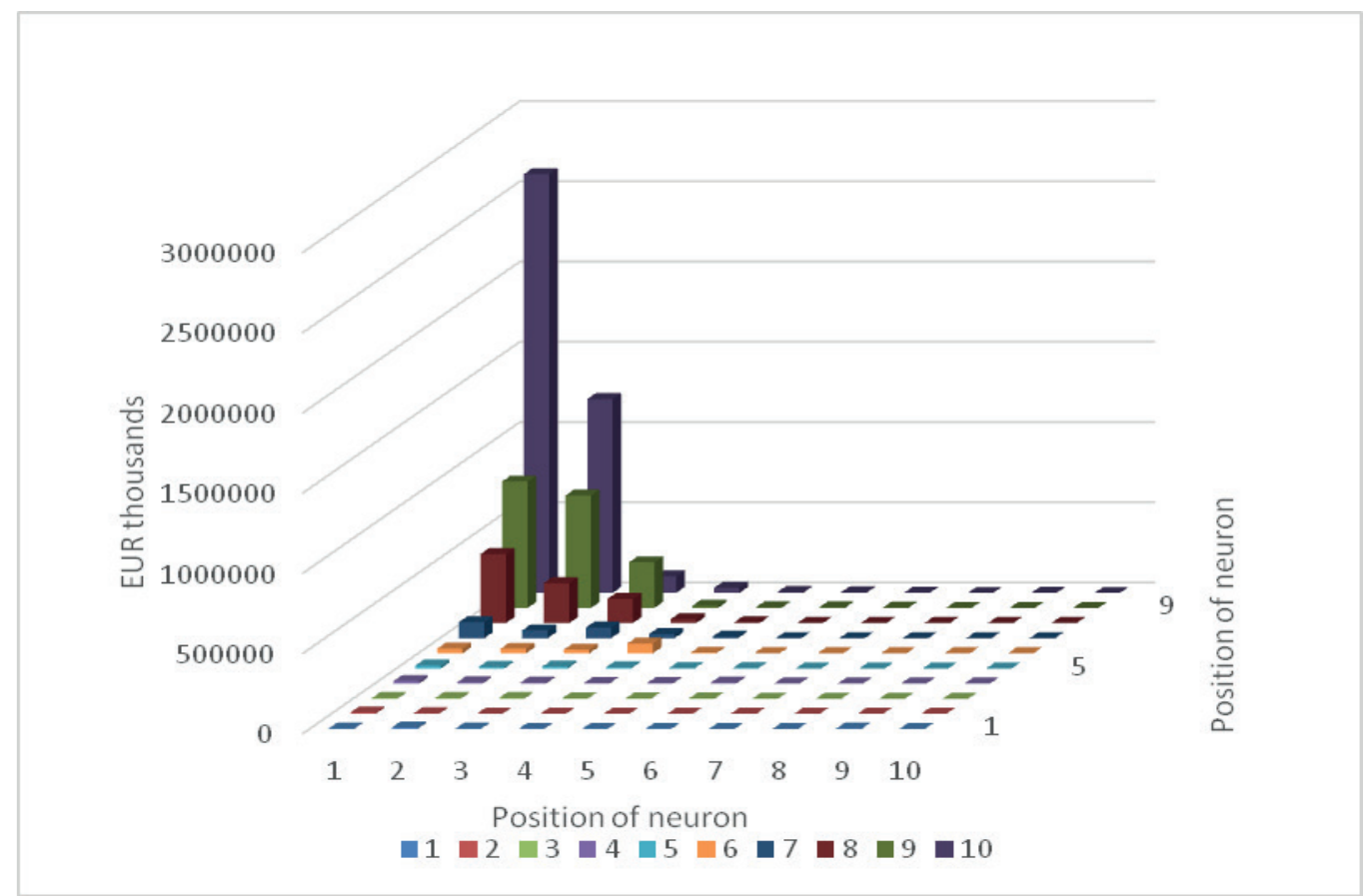

Figure 2 Average value of corporate fixed assets per cluster

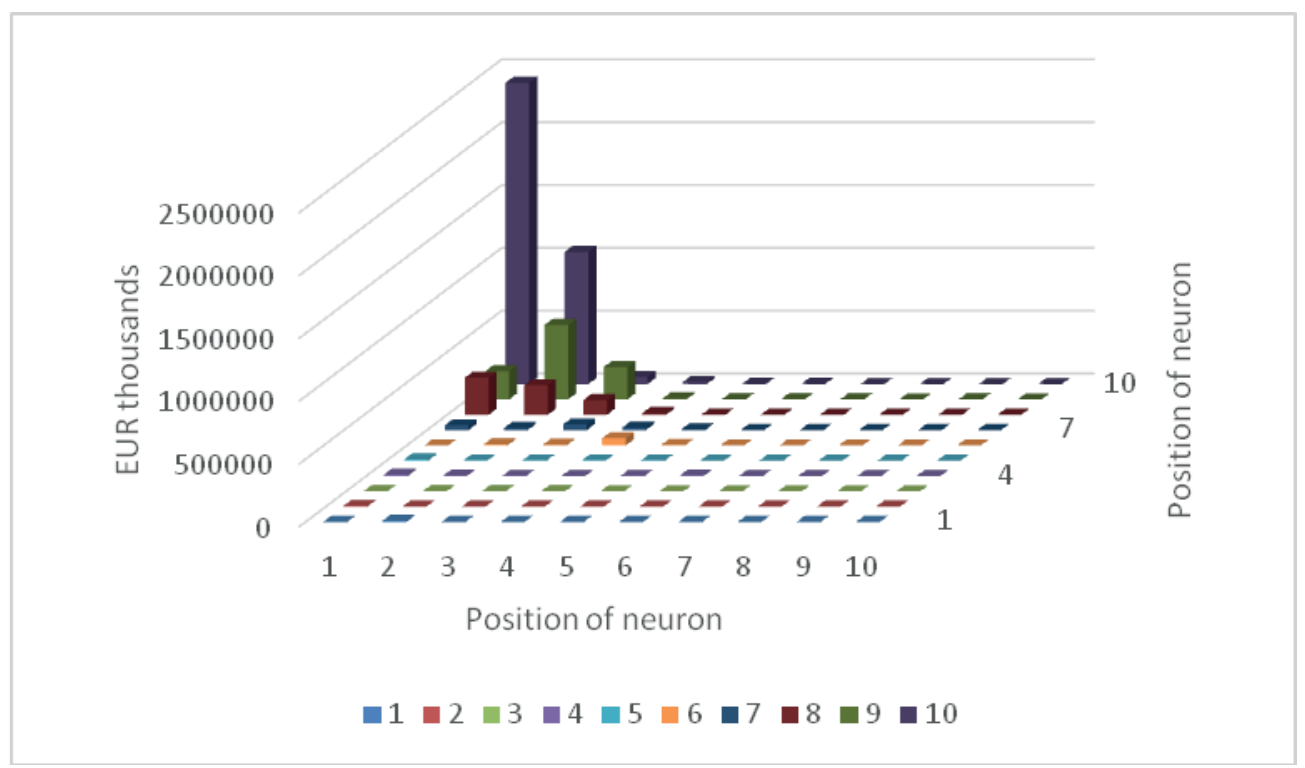

Figure 3 Average value of total corporate assets per cluster

In addition to fixed assets, an interesting indicator is total assets of an average company per cluster (Figure 3).

The total volume of assets predetermines the ability of the company to generate production. In particular, they include two out of three production factors [27] - i.e. fixed assets and material. The third production factor, human labour, is impossible to keep on store, thus it cannot be measured before the moment of consumption. The figure shows a very high value of average assets in Cluster $(10,1)$.

Clusters $(10,2),(9,2),(8,1),(9,3),(8,2)(9,1)$ and $(8,3)$ show much lower values of the average total assets, however, still higher above the average.

There is another average value, which is very strong, namely operating profit.
The average operating profit (Figure 4) allows comparing the success of companies in different clusters.

Different sizes of companies are compared (although average parameters). Companies in Cluster $(10,2)$ appear to be the most successful. They are immediately followed by Clusters $(10,1),(9,2),(6,1)$ and $(9,1)$. In addition, note Clusters $(8,2),(8,1),(5,2)$ and $(9,3)$. The results of Clusters $(6,1)$ and $(6,2)$ are definitely very interesting. In terms of results, both clusters, in particular Cluster $(6,1)$, may easily compete with companies from clusters, which dispose of much more capital and fixed assets. It means that their management and administration are very effective, or they offer services with high value added. Or additionally, we can assume that sales are partly realized outside the transportation sector and their secondary activity is very 


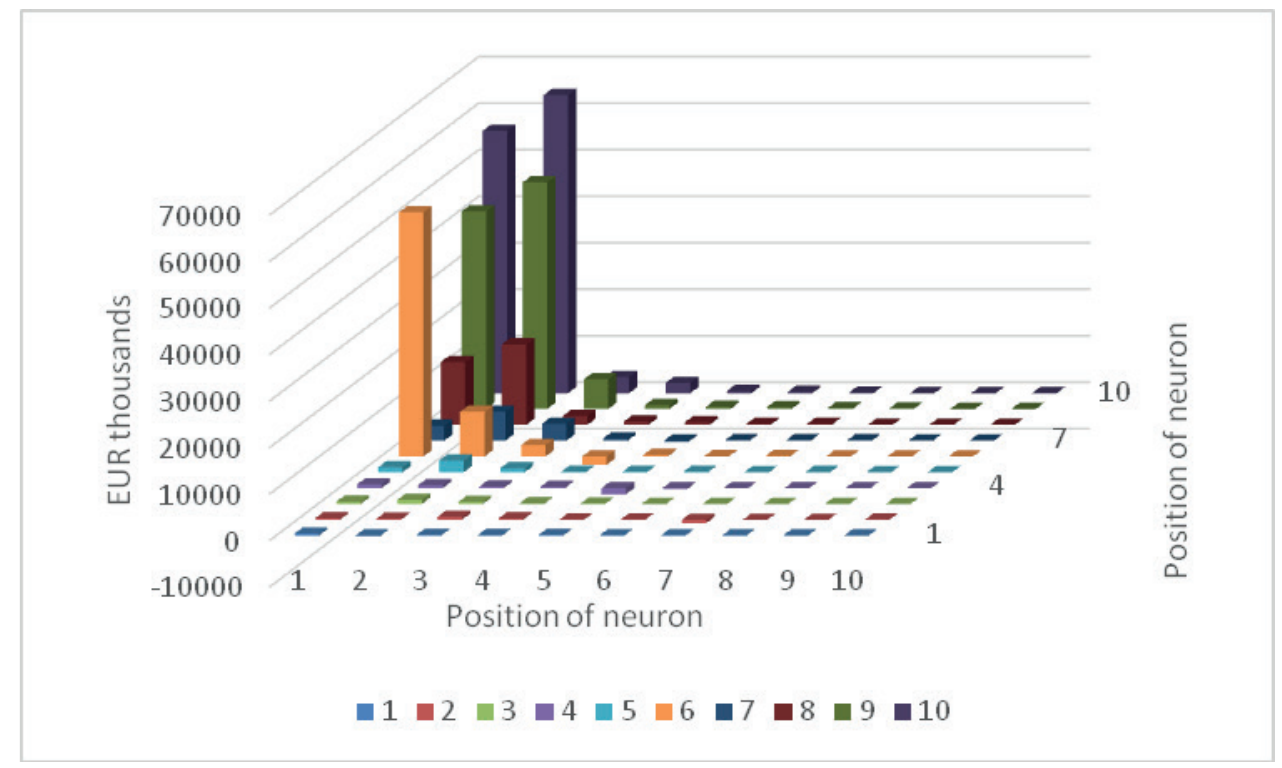

Figure 4 Average operating profit per cluster

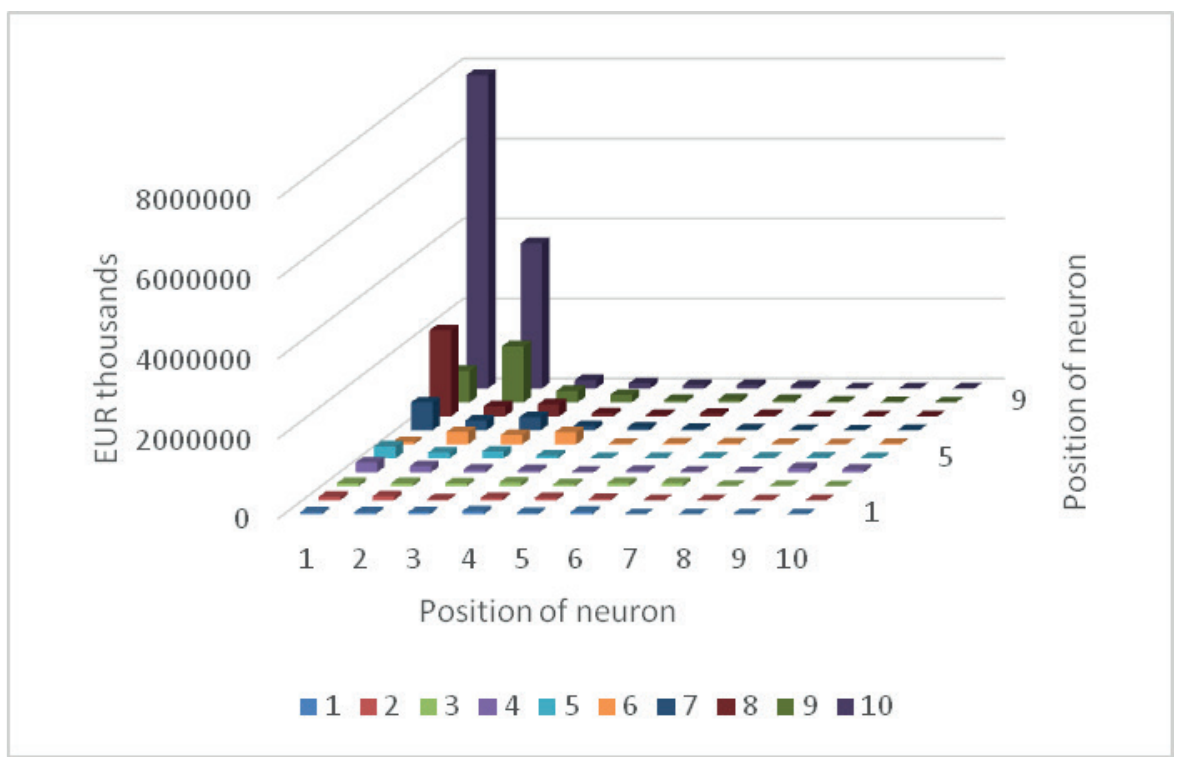

Figure 5 Assets owned by companies per cluster

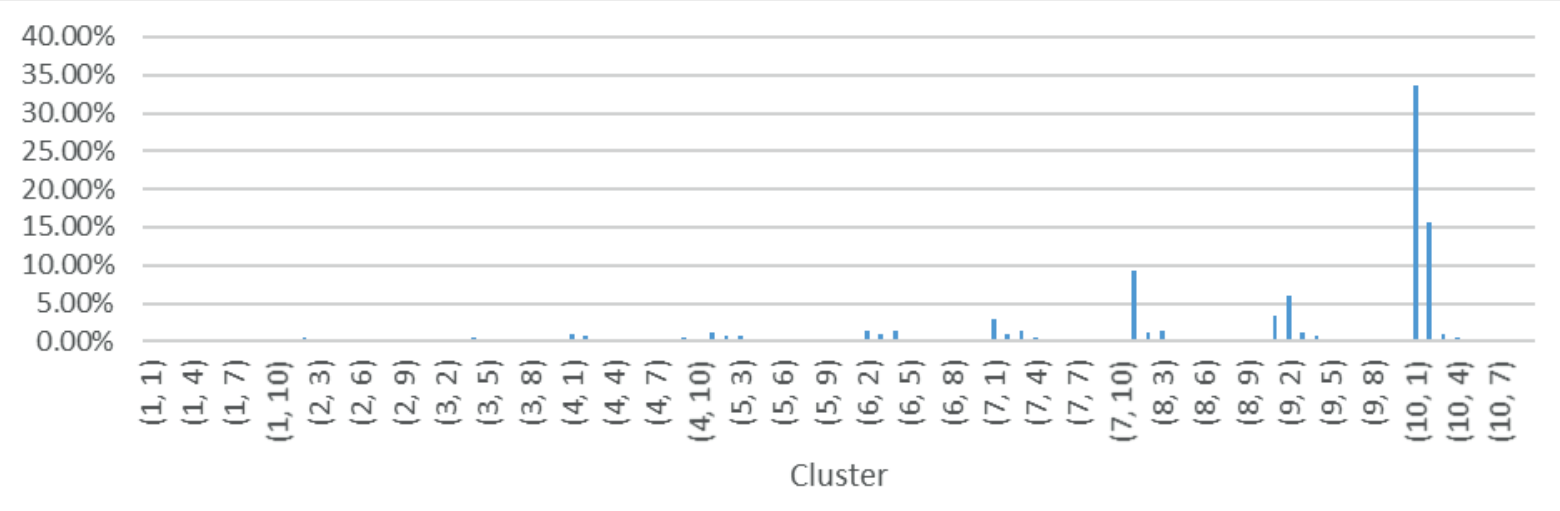

Figure 6 Cluster shares of assets in the transportation industry 


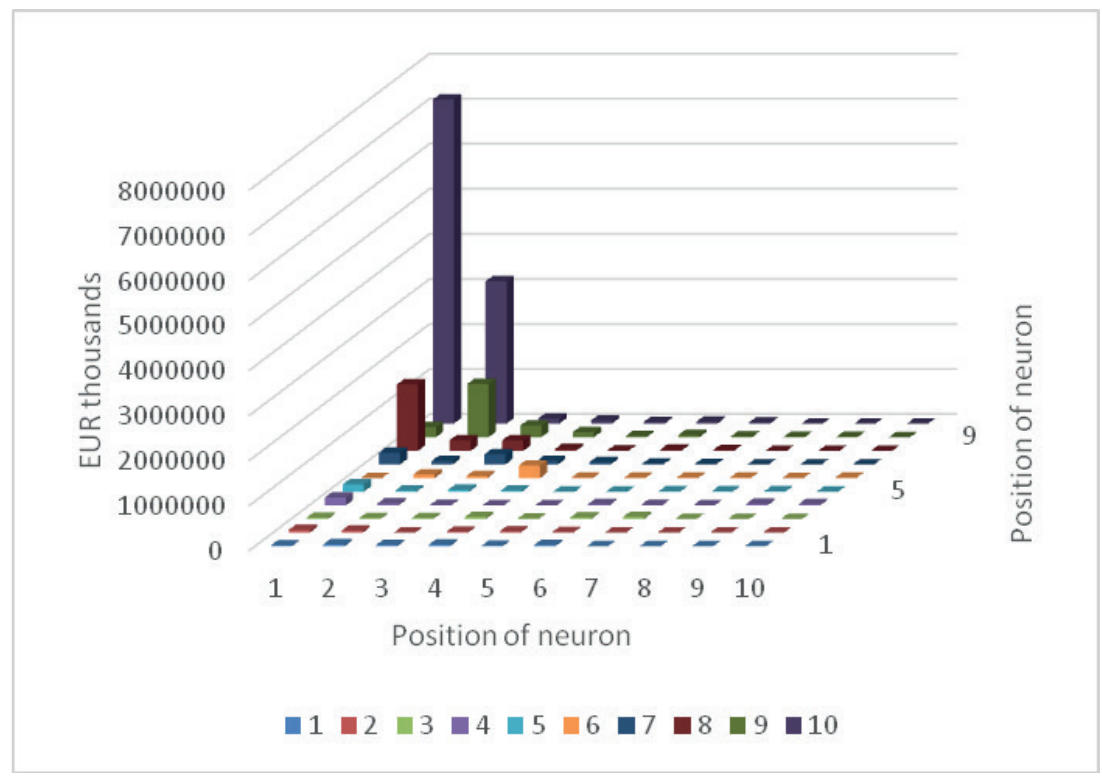

Figure 7 Fixed assets owned by companies per cluster

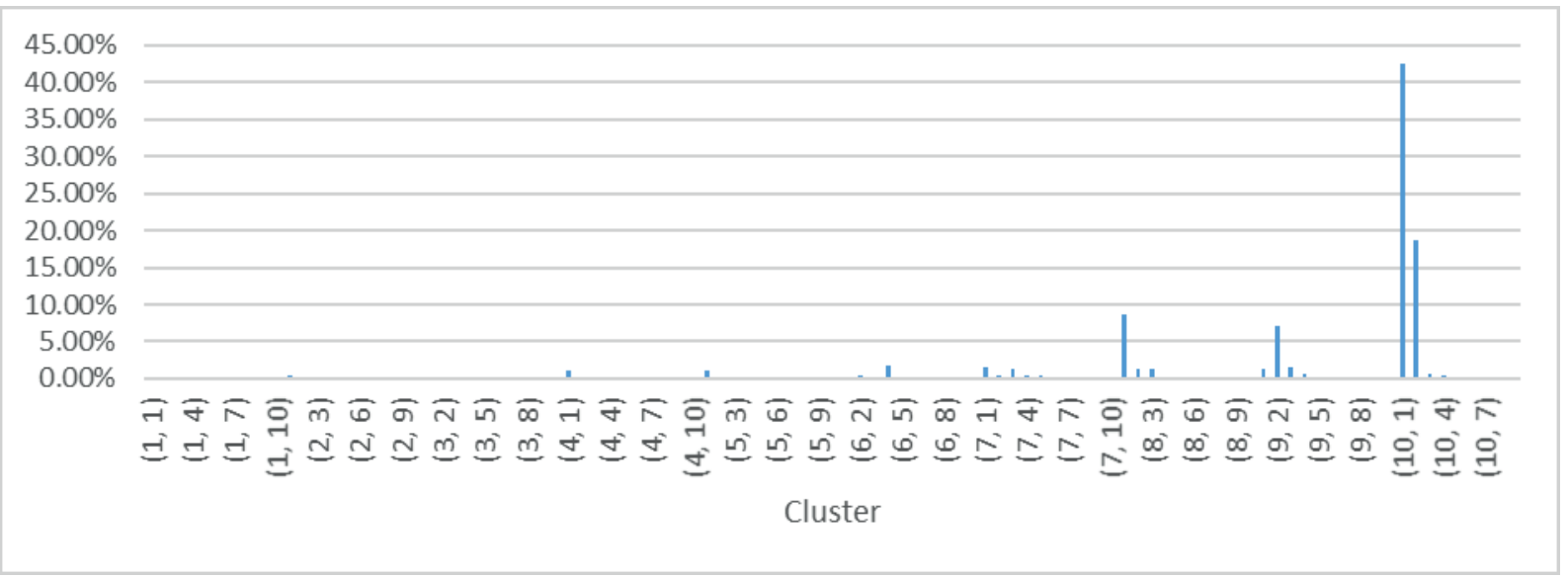

Figure 8 Cluster shares of fixed assets in the transportation industry

effective. In terms of efficiency (measured by the total and fixed assets to operating profit ratio), Cluster $(6,1)$ is considered as the most successful. On the other hand, the least successful companies are included in Cluster $(6,4)$ with realized operating loss exceeding on average EUR 1.8 million. This loss is in big contrast to their total assets and fixed assets. It can be deduced that the fixed assets are not used efficiently by those companies, or that just a small part of their fixed assets can be referred to as necessary for operation.

\subsection{Analysis of absolute indicators}

As previously mentioned, the analysis of absolute indicators should reveal how much each company cluster is important for the entire transportation industry in the Czech Republic. The same parameters, as in the case of average values analysis, were analyzed.

Figure 5 shows the absolute amount of fixed assets owned by companies pertaining to the same cluster.
The graph shows that the most of assets are owned by companies in Cluster $(10,1)$. The companies in this cluster dispose of the total assets amounting to nearly EUR 7,851 billion. The companies in Cluster $(10,2)$ own total assets exceeding EUR 3.61 billion. The companies allocated to Clusters $(8,1),(9,2),(9,1)$ and $(7,1)$ also dispose of total assets exceeding EUR 393 million. This interesting information is completed by cluster shares of the owned capital (Figure 6).

The graph shows that companies in Cluster $(10,1)$ own nearly $35 \%$ of all the assets in the transportation sector of the Czech Republic. The companies in Cluster $(10,2)$ own more than $15 \%$ assets of the transportation industry. Eventually, the companies in Cluster $(8,1)$ own $9.26 \%$ of all assets in the transportation sector of the Czech Republic. It has been expected that clusters large in numbers also appear in absolute parameters. However, that was not the case. Cluster $(4,10)$ representing 919 companies, i.e. more than $23 \%$ of the studied companies, represents only $0.28 \%$ of the total assets.

The fixed assets was another parameter examined (Figure 7). 


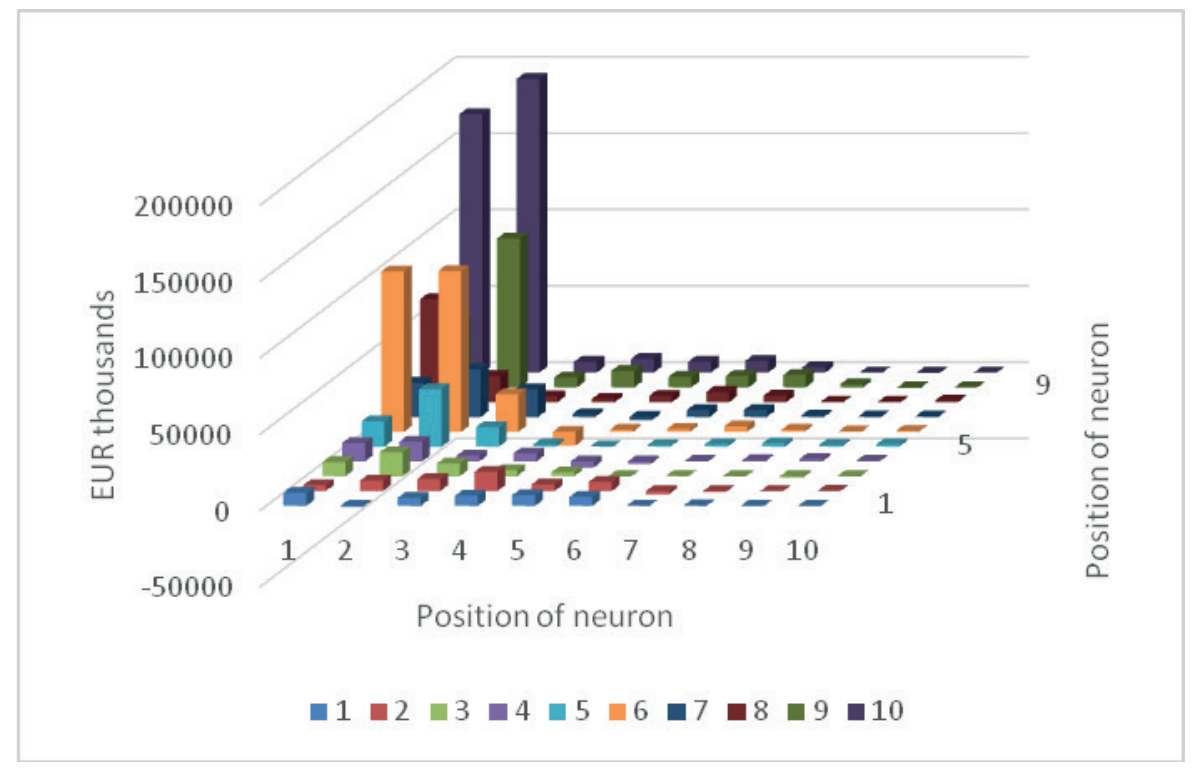

Figure 9 Realized operating profit of companies per cluster

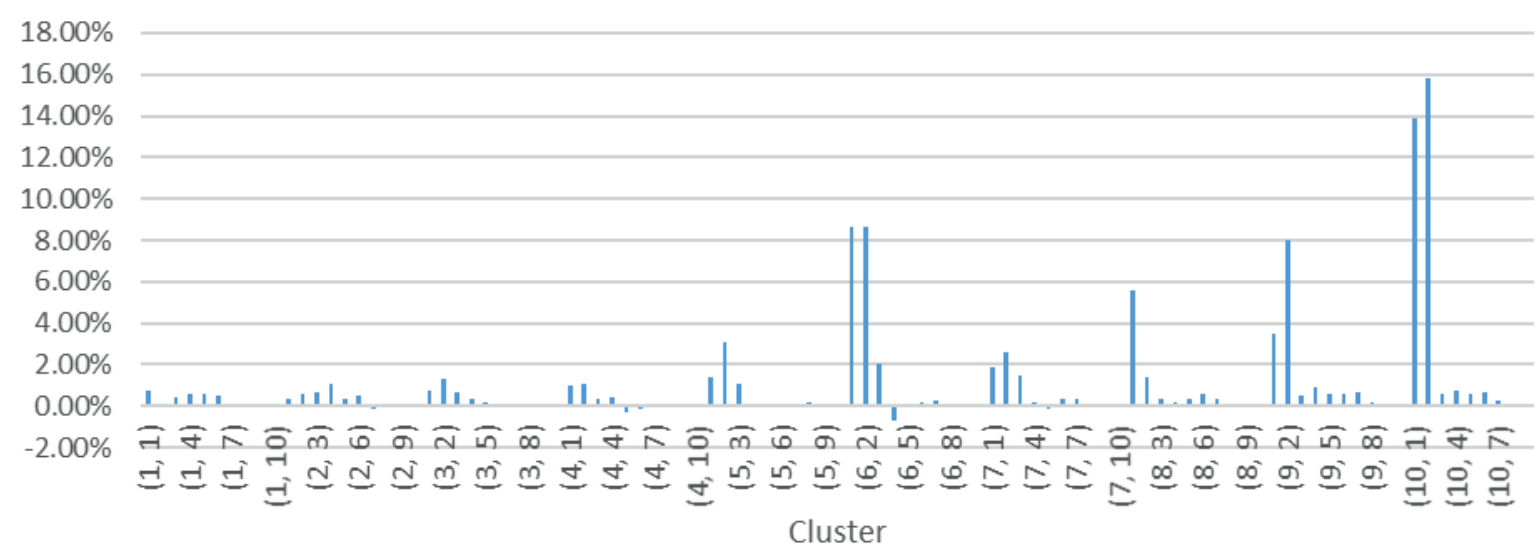

Figure 10 Cluster shares of the operating profit realized in the transportation industry

The graph shows again that the most of fixed assets are owned by companies in Cluster $(10,1)$. They register the aggregate value of fixed assets over EUR 7.18 billion. Clusters $(10,2),(8,1)$ and $(9,2)$ also dispose of considerable fixed assets. All the identified clusters each dispose of fixed assets of billions of EUR. The situation was clarified based on a relative comparison of companies - namely the share of total owned fixed assets in the transportation sector (Figure 8).

The graph in Figure 9 indicates that companies in Cluster $(10,1)$ own more than $42 \%$ of the fixed assets employed in the transportation industry. Then $18.64 \%$ belongs to companies in Cluster (10, 2); $8.7 \%$ is owned by Cluster (8, 1) and less than $7 \%$ by Cluster $(9,2)$. The percentage of the fixed assets, employed in the transportation industry, owned by companies in Cluster $(4,10)$ is only $0.19 \%$.

Figure 9 provides a comparison of absolute operating profits.

From the graph results that Cluster $(10,2)$ is definitely the most successful cluster in terms of operating profit. It generates a total income of less than EUR 192.4 million. It is followed by Cluster $(10,1)$ with operating profit exceeding EUR 164.9 million. Those two are followed by Clusters (6, $2),(6,1)(9,2),(8,1)$ and $(5,2)$. See Figure 10 for illustration.

Figure 10 shows the predominance of Cluster $(10,2)$. In 2016 it generated nearly $15.8 \%$ of operating profit of the entire transportation industry. Cluster $(10,1)$ realized nearly $15 \%$ of operating profit across the Czech transportation industry in the reference period. Clusters $(6,2),(6,1)$ and $(8,1)$ are also ranged above $8 \%$ of the total profit from operations in the transportation industry. The largest Cluster $(4,10)$ shares are $-0.00083 \%$ in the profits from operations of the Czech transportation industry.

It was also interesting to compare the return of equity (ROE) of different clusters (see Figure 11 for more details).

The graph does not show ROE values for clusters where companies achieved values outside the interval $-500 \%$ to $+500 \%$. Those were senseless values of clusters where only one company was represented at each time. The values outside the interval would cause a high distortion of outputs from the graph in Figure 11. Whether the interval was not too large is still a question. The ROE (return 


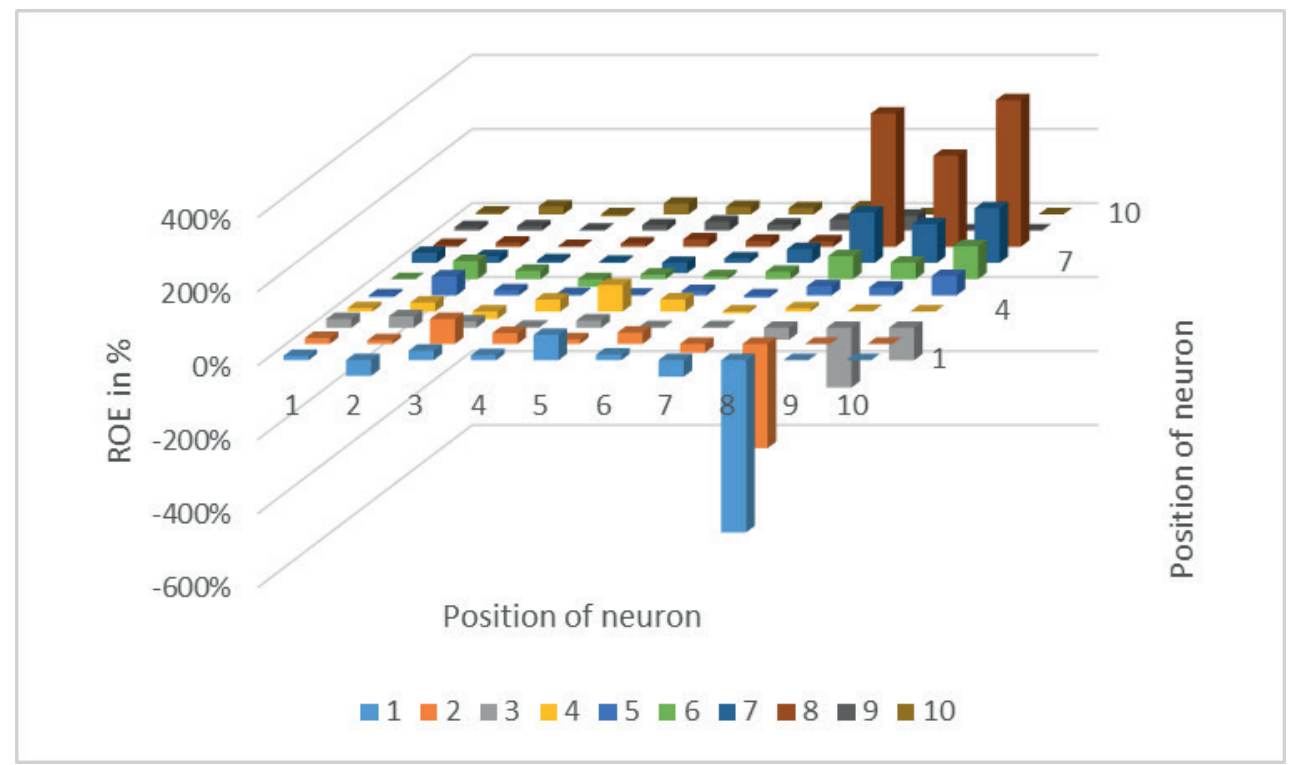

Figure 11 ROE comparison of clusters in the transportation industry

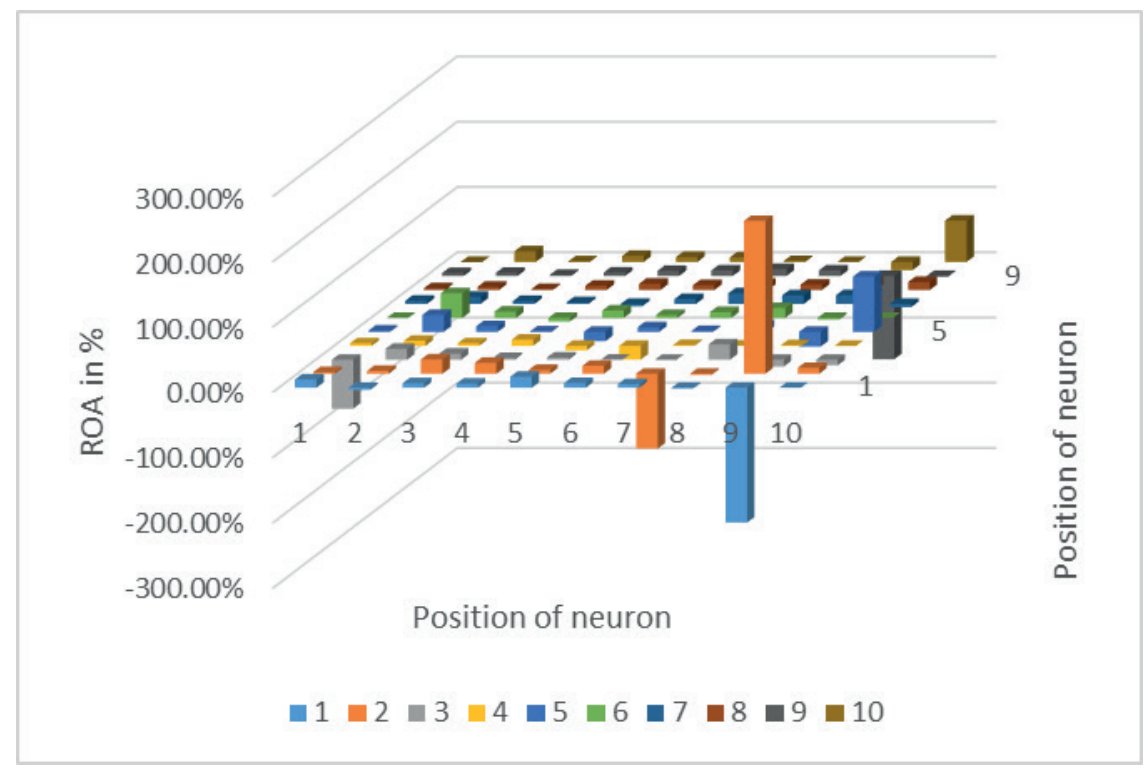

Figure 12 ROA comparison of company clusters in the transportation industry

Table 2 Leaders in the transportation industry 2016

\begin{tabular}{ccccc}
\hline row description & $\begin{array}{c}\text { number of companies } \\
\text { in a cluster }\end{array}$ & $\begin{array}{c}\text { fixed assets } \\
\text { (in EUR) }\end{array}$ & $\begin{array}{c}\text { total assets } \\
\text { (in EUR) }\end{array}$ & $\begin{array}{c}\text { operating profit } \\
\text { (in EUR) }\end{array}$ \\
\hline$(10,2)$ & 3 & $3,158,116,467$ & $3,626,118,037$ & $192,304,809$ \\
$(10,1)$ & 3 & $7,193,464,181$ & $7,830,443,415$ & $169,191,482$ \\
$(6,2)$ & 11 & $82,295,388$ & $310,578,842$ & $105,335,191$ \\
$(6,1)$ & 2 & 123,062 & $58,153,759$ & $103,901,418$ \\
$(9,2)$ & 2 & $1,185,279,686$ & $1,403,650,638$ & $97,468,106$ \\
$(8,1)$ & 5 & $1,473,422,493$ & $2,152,522,473$ & $67,550,854$ \\
$(9,1)$ & 1 & $224,062,807$ & $788,537,782$ & $42,512,267$ \\
$(5,2)$ & 61 & $30,765,810$ & $145,671,717$ & $37,633,091$ \\
\hline total & 88 & $13,347,529,890$ & $16,315,676,660$ & $816,998,430$ \\
\hline $\begin{array}{l}\text { percentage } \\
\text { of the total }\end{array}$ & $2.21 \%$ & $78.77 \%$ & $70.17 \%$ & $67.10 \%$ \\
\hline
\end{tabular}


on equity) provides information on the appreciation for deposits of the owners. The best would be only to consider taxed equity for calculation. In this case, however, all the equity was used. The indicator is considered as one of the key indicators of the company's success. The value is typically compared to profitability of other investment opportunities on the market. Weakness of the ROE comes from the fact that it does not take into account the risk of investment opportunities. Several values are visible in the figure. The best results are reported by clusters in another part of the Kohonen map. Specifically, Clusters $(8,10),(8$, $8)$ and $(8,9)$ followed by Clusters $(7,10),(7,8)$ and $(7,9)$. Conversely, the worst results are presented by Clusters (1, 8 ) and $(2,8)$. The most profitable Cluster $(10,2)$ achieved an ROE of $21.35 \%$. Cluster $(10,1)$, the largest cluster in terms of the total assets, had an ROE about $4.65 \%$. In terms of operating profit, the successful Cluster $(6,1)$ achieved an ROE outside of the present range, Cluster $(6,2)$ then had an ROE of $49 \%$. The largest Cluster $(4,10)$ achieved an average ROE of $-0.19 \%$.

Return on assets (ROA) was analysed as the second ratio indicator (Figure 12).

The ROA as the indicator evaluates the ability of assets to make profit. The value of this indicator is based on the ratio of the two underlying parameters - namely assets and profit. Thus, the relatively small companies may achieve attractive results similar to large companies. The ROA indicator is fairly high for a number of clusters. Cluster (2, 9 ) is the most successful cluster. The value is about $234.1 \%$. Conversely, the worst result was achieved by Cluster $(2,9)$. In this case, the cluster value is highly negative, specifically $-206.5 \%$.

\section{Discussion of results}

The aforementioned analyses clearly demonstrate that Clusters $(10,2),(10,1),(6,2),(6,1),(9,2),(8,1),(9,1)$ and $(5,2)$ are the most important for the transportation industry in terms of the total assets, fixed assets and profit-making. Clusters $(10,2)$ and $(10,1)$ are each formed only by three companies. Still, they dispose of the largest amount of assets and fixed assets as well as they achieve the highest profit from operations in the industry.

Note that the total of 3,989 companies were active in the Czech transportation industry in 2016. Considering all the analyses, one can conclude that industry leaders are the representatives of Clusters $(10,2),(10,1),(6,2),(6,1)$, $(9,2),(8,1),(9,1)$ and $(5,2)$. Table 2 summarizes the most successful clusters.

The identified group of leaders in the transportation industry consists of 88 companies, out of which 61 are allocated to Cluster $(5,2)$, of the total of 3,989 . Thus, it makes $2.21 \%$ of all the companies that were active in the industry during the reference period. Those 88 companies own $78.77 \%$ of all fixed assets allocated to transportation in the Czech Republic. At the same time, they own 70.17\% of all the assets concentrated in the industry. A total of
$67.10 \%$ of the profit from operations in the entire industry is generated by 88 companies.

\section{Conclusions}

The aim of this paper was to analyse transportation in the Czech Republic with Kohonen networks. The analysis was supposed to identify industry leaders.

The Kohonen networks were used for cluster analysis. There were 3,989 companies active in the transportation industry in 2016 and they were classified into 100 clusters (the Kohonen map was predefined using the mesh topology $10 \times 10)$. All the clusters were analysed. Cluster $(4,10)$ was the largest one. Still, this cluster is not crucial for development of the transportation industry in the Czech Republic. On the contrary, the transportation industry is strongly influenced by companies of Clusters $(10,1)$ and $(10,2)$. Those clusters include only 6 companies. Nevertheless, their average values are highly above those of all the other companies active in the industry. In addition, their absolute indicators surmount all the other clusters. Still, there are other clusters, which have no small influence on development of the transportation industry in the Czech Republic, namely clusters $(6,2),(6$, $1),(9,2),(8,1),(9,1)$ and $(5,2)$. On overall, 88 companies can be referred to as leaders in the transportation industry although the importance of companies in Cluster (5, 2 ), which includes 61 companies can be looked at. The conclusion is that a relatively small group of companies have a major influence on development of transportation in the Czech Republic. If one should speculate, it can be said that this group has a great influence on development on the entire national economy. The reason lies in the nature of the transportation industry. The result implies that the future development of the entire transportation industry can be predicted based on results of 88 companies. The other companies, with a view to their number and partial low influence on development of the industry, provide a certain hotbed, which is not going to change a lot in the aggregated form. As a prediction tool, the analysis of 88 companies seems very positive. However, the negative fact is that fluctuations in production (no matter what is the cause) can result in fluctuations in the entire industry if not the entire national economy.

Further research should then focus on:

- Identifying whether the representation of companies in different clusters changes over time, in particular for clusters where leaders in the transportation industry come from (both the number and the form of specific companies - especially for Clusters $(10,1)$ and $(10,2)$.

- Verifying the ability to predict development of the transportation industry based on analysis of industry leaders.

- Identifying how potential fluctuations in economic results of the leaders have affected development of the transportation industry, in particular with accent on Clusters $(10,1)$ and $(10,2)$. 


\section{References}

[1] HORAK, J., KRULICKY, T. Comparison of exponential time series alignment and time series alignment using artificial neural networks by example of prediction of future development of stock prices of a specific company. In: SHS Web of Conferences: Innovative Economic Symposium 2018 - Milestones and Trends of World Economy IES2018: proceedings [online]. Vol. 61. SHS Web of Conferences, 2019. eISSN 2261-2424. Available from: https://doi.org/10.1051/ shsconf/20196101006

[2] VOCHOZKA, M. Formation of complex company evaluation method through neural networks based on the example of construction companies collection. Ad Alta: Journal of Interdisciplinary Research. 2018, 7(2), p. 232-239. ISSN 2464-6733.

[3] MACHOVA, V., VOCHOZKA, M. Analysis of business companies based on artificial neural networks. In: SHS Web of Conferences: Innovative Economic Symposium 2018 - Milestones and Trends of World Economy IES2018: proceedings [online]. Vol. 61. SHS Web of Conferences, 2019. eISSN 2261-2424. Available from: https://doi.org/10.1051/ shsconf/20196101013

[4] SVOBODOVA, H., VEZNIK, A., HOFMANN, E. Vybrane kapitoly ze socioekonomicke geografie Ceske republiky / Selected chapters from socioeconomic geography of the Czech Republic (in Czech). 1. ed. Brno: Masaryk University, 2013. ISBN 978-80-210-6229-0.

[5] KLIESTIK, T. Models of autoregression conditional heteroskedasticity GARCH and ARCH as a tool for modeling the volatility of financial time series. Ekonomicko-manazerske spektrum. 2013, 7(1), p. 2-10. ISSN 1337-0839.

[6] PAO, H. A comparison of neural network and multiple regression analysis in modeling capital structure. Expert Systems with Applications [online]. 2008, 35(3), p. 720-727. ISSN 0957-4174. Available from: https://doi.org/10.1016/j. eswa.2007.07.018

[7] HORAK, J., VOCHOZKA, M., MACHOVA, V. Evaluation of transport and forwarding companies by means neural networks. In: Proceedings of the Interdisciplinary Scientific International Conference for PhD Students and Assistants QUAERE 2018: proceedings. 2018. p. 377-385.

[8] SAYADI, A. R., TAVASSOLI, S. M. M., MONJEZI, M., REZAEI, M. Application of neural networks to predict net present value in mining projects. Arabian Journal of Geosciences [online]. 2012, 7(3), p. 1067-1072. ISSN 1866-7511, eISSN 1866-7538. Available from: https://doi.org/10.1007/s12517-012-0750-z

[9] MACHOVA, V., ROWLAND, Z. Value generators of enterprises in the processing industry. In: Proceedings of the 6th International Conference Innovation Management, Entrepreneurship and Sustainability IMES2018: proceedings. 2018. ISBN 978-80-245-2274-6, p. 624-634.

[10] GRIGORYEVA, N. Y., ZHANGIROV, T. R., PERKOV, A. S., IVANOVA, S. A., LISS, A. A. Classifying neural networks and methods of their illogical behaviour revealing. Journal of Physics: Conference Series [online]. 2019, $1352,012024$. ISSN 1742-6588. Available from: https://doi.org/10.1088/1742-6596/1352/1/012024

[11] VOCHOZKA, M., MACHOVA, V. Determination of value drivers for transport companies in the Czech Republic. Nase More [online]. 2018, 65(4), p. 197-201. ISSN 1848-6320. Available from: https://doi.org/10.17818/NM/2018/4SI.6

[12] VOCHOZKA, M., SHENG, P. The application of artificial neural networks on the prediction of the future financial development of transport companies. Communications - Scientific Letters of the University of Zilina [online]. 2016, 18(2), p. 62-67. ISSN 1335-4205, eISSN 2585-7878. Available from: http://komunikacie.uniza.sk/index.php/ communications/article/view/331

[13] KONECNY, V., TRENZ, O., SVOBODOVA, E. Classification of companies with the assistance of self-learning neural networks. Agricultural Economics - Zemedelska Ekonomika [online]. 2010, 56(2), p. 51-58. ISSN 0139-570X. Available from: https://doi.org/10.17221/60/2009-AGRICECON

[14] HAN, X., WANG, L. Stock company comprehensive assessment model based on Kohonen network. In: 2008 Second International Conference on Genetic and Evolutionary Computing: proceedings [online]. 2008. ISBN 978-0-7695-3334-6, p. 185-188. Available from: https://doi.org/10.1109/WGEC.2008.97

[15] KRULICKY, T. Using Kohonen networks in the analysis of transport companies in the Czech Republic. In: SHS Web of Conferences: Innovative Economic Symposium 2018 - Milestones and Trends of World Economy: proceedings [online]. 2019. ISBN 978-2-7598-9063-7. Available from: https://doi.org/10.1051/shsconf/20196101010

[16] SEVERIN, E. Self organizing maps in corporate finance: quantitative and qualitative analysis of debt and leasing. Neurocomputing [online]. 2010, 73(10-12), p. 2061-2067. ISSN 0925-2312. Available from: https://doi.org/10.1016/j. neucom.2009.12.024

[17] CHEN, N., RIBEIRO, B., VIEIRA, A., CHEN, A. Clustering and visualization of bankruptcy trajectory using selforganizing map. Expert Systems with Applications [online]. 2013, 40(1), p. 385-393. ISSN 0957-4174. Available from: https://doi.org/10.1016/j.eswa.2012.07.047

[18] LIN, W. Y., HU, Y. H., TSAI, C. F. Machine learning in financial crisis prediction: a survey. IEEE Transactions on Systems, Man, and Cybernetics, Part C - Applications and Reviews [online]. 2012, 42(4), p. 421-436. ISSN $1094-6977$. Available from: https://doi.org/10.1109/TSMCC.2011.2170420 
[19] HITKA, M., LORINCOVA, S., LIZBETINOVA, L., PAJTINKOVA BARTAKOVA, G., MERKOVA, M. Cluster analysis used as the strategic advantage of human resource management in small and medium-sized enterprises in the wood-processing industry. BioResources [online]. 2017, 12(4), p. 7884-7897. Available from: https://doi.org/10.15376/biores.12.4.78847897

[20] VRBKA, J., ROWLAND, Z. Stock price development forecasting using neural networks. In: SHS Web of Conferences: Innovative Economic Symposium 2017 - Strategic Partnerships in International Trade: proceedings [online]. Vol. 39. 2017. Available from: https://doi.org/10.1051/shsconf/20173901032

[21] LEHUTOVA, K., KRIZANOVA, A., KLIESTIK, T. Quantification of equity and debt capital costs in the specific conditions of transport enterprises. In: 17th International Conference on Transport Means: proceedings. 2013. ISSN 1822-296X, p. 258-261.

[22] KAMPF, R., LORINCOVA, S., HITKA, M., STOPKA, O. Generational differences in the perception of corporate culture in European transport enterprises. Sustainability [online]. 2017, 9(9), p. 1-14. ISSN 2071-1050. Available from: https://www.mdpi.com/2071-1050/9/9/1561

[23] HRASKOVA, D., BARTOSOVA, V. Emergent approach to management of the transport company. In: 2nd International Conference on Social Sciences Research: proceedings. 2014. ISBN 978-967-11768-7-0, p. 92-96.

[24] OU, X., YAN, X., ZHANG, X., LIU, Z. Life-cycle analysis on energy consumption and GHG emission intensities of alternative vehicle fuels in China. Applied Energy [online]. 2012, 90(1), p. 218-224. ISSN 0306-2619. Available from: https://doi.org/10.1016/j.apenergy.2011.03.032

[25] VOCHOZKA, M., ROWLAND, Z., VRBKA, J. Financial analysis of an average transport company in the Czech Republic. Nase More [online]. 2016, 63(3), p. 227-236. ISSN 0469-6255. Available from: https://doi.org/10.17818/NM/2016/SI28

[26] SEROKA-STOLKA, O., TOMSKI, P., PABIAN, A. Environmental strategies in the management of transport. In: 4th International Conference on Advanced Logistics and Transport ICALT 2015: proceedings. 2015. ISBN 978-1-4799-8400-8, p. 122-127.

[27] WOHE, G., KISLINGEROVA, E. Uvod do podnikoveho hospodarstvi / Introduction to business economy (in Czech). 2. ed. Prague: C. H. Beck, 2007. ISBN 978-80-7179-897-2. 